\title{
TRANSFORMATION OF HISTORY IN THE GLASS PALACE AND BURNT SHADOWS: A POSTMODERNIST ANALYSIS
}

\author{
Ayesha Ashraf* \\ Munawar Iqbal Ahmed **
}

\begin{abstract}
South Asian English fiction, in recent decades, has significantly manifested its deepest concern for history and its relevance in the contemporary global scenario. The last couple of years have noticed the publication of many English novels by Indian and Pakistani authors that in fact belong to the very genre of postmodern historiographic metafiction. In fact, postmodern fiction writers usually deviate from the traditional representation of past events. The current study examines the way history writing is reconfigured in the selected postmodern novel. In these novels, the writers retell the traditional history through innovative narrative techniques and multiplicity of the views that de-centralize the conventional history. The present research attempts to explore Amitav Gosh's The Glass Palace and Kamila Shamsie's Burnt Shadows as historiographic metafiction, that is a sub-genre of postmodern fiction. The study focuses on the selected texts to explore how these novels transform the traditional history through the incorporation of magic realism, intertextuality and self-reflexivity. This research is qualitative and descriptive, while the textual analysis has been used as a research method. The theoretical concept of Linda Hutcheon is incorporated in this current study that ends with findings and recommendations for future research.
\end{abstract}

Keywords: Narrative, postmodernism, historiographic metafiction, novel, Linda Hutcheon

\section{Introduction}

Postmodernism, in the 1970s, started a debate in literature and it emerged as an extension or a reaction against modernism. It spread a sense of something completed, ended and over, in the thought, culture, and life, especially in the second half of the twentieth century. Jean Francois Lyotard refers to this movement as 'incredulity towards metanarratives ${ }^{1}$ as it challenges the existing perceptions and thought patterns which are based on claims of objectivity and truth. Postmodernism influenced every field of art ranging from music, philosophy, architecture, culture, history, and literature; hence it changed the existing trends. However, with the advent of postmodern philosophy, history writing took a new turn. In fact, in the second half of the 20th century, many philosophers and critics of history and literary studies such as Hayden White, Linda Hutcheon, Alun Munslow and Keith Jenkins started debating the connection between literature and

\footnotetext{
"Ayesha Ashraf, Ph.D. Scholar, NUML Islamabad

${ }^{* * *}$ Munawar Iqbal Ahmed, Ph.D and Ex-Dean Faculty of Languages and Literature, IIU Islamabad.

${ }^{1}$ Jean-François Lyotard. The Postmodern Condition: A Report on Knowledge. Vol. 10. (U of Minnesota Press, 1984)
} 
history. History stands for interpretations of the past and it is actually to look back at the events, As Keith Jenkins states that; "history is one of the series of discourses about the world, a way of appropriating (not creating) the world and giving it all the meaning it has". ${ }^{2}$ This study focuses on the seminal work of Linda Hutcheon, A Poetics of Postmodernism: History, Theory, Fiction (1988), which is quite significant in analyzing the selected texts in terms of the representation of history. Hutcheon holistically categorizes all the postmodern historical fiction as "historiographic metafiction" to describe the fiction which "uses metafictional techniques to remind us that history is a construction, not something natural that equates to the past". ${ }^{3}$ As per her argumentation, Burnt Shadows and The Glass Palace present a good example of how traditional historiography is resisted and challenged through using metafictional techniques.

Contemporary historical novels are labeled as Historiographic Metafiction by the famous Canadian theorist Linda Hutcheon in her seminal book, A Poetics of Postmodernism. She states that this postmodern genre differs from modern history in the sense that it portrays history as a fiction and a construction. Moreover, it challenges the modern concept that history can be presented in an objective or unbiased way. Postmodern historiographic metafiction self-consciously relates the workings of history and fiction as it regards that whatever is found about the history, is available only in written form or constructed form as the past is not a given truth which can be empirically apprehended by a historian. Historiographic metafiction, as a sub-genre of postmodern fiction, questions the totality of traditional history as Teaching the Postmodern states that:

\begin{abstract}
Postmodernism is about history. But not the kind of 'History' that lets us think we can know the past. History in the postmodern moment becomes histories and questions. It asks: Whose history gets told? In whose name? For what purpose? Postmodernism is about histories not told, retold, untold. History as it never was. Histories forgotten, hidden, invisible, considered unimportant, changed, eradicated. It's about the refusal to see history as linear, as leading straight up to today in some recognizable pattern-all set for us to make sense of. It's about chance. It's about power. It's about the information. And more information. ${ }^{4,5}$
\end{abstract}

English fiction writers, from Pakistan and India, use many characteristics of historiographic metafiction in their works such as Salman Rushdie's Midnight's Children, Amitav Gosh's Sea of Poppies, Muhammad Hanif's A Case of Exploding Mangoes, Bapsi Sidhwa's Cracking India and Khushwant Singh's Train to Pakistan and many other. Amitav Gosh's creative endeavor consists of both fictional and non-fictional works as he; being anthropologist, writer, and academician, has focused on the diversity and rich cultural heritage of India in his fiction. His profound concern for India is quite evident in his style of using India as a fictional setting, in most of his novels. Therefore, his fiction includes The Circle of Reason (1986), The Shadow Lines (1988), The Calcutta Chromosome (1995), The Glass Palace (2000), The Hungry Tide (2004), and Sea of

\footnotetext{
${ }^{2}$ Keith Jenkins, Re-thinking History: (London: Routledge, 1991). 20.

${ }^{3}$ Bran Nicole. The Cambridge Introduction to Postmodern Fiction: (Cambridge: Cambridge UP, 2009). 99.

${ }^{4}$ Brenda Marshall. Teaching the Postmodern. (London: Routledge, 2013), 4

${ }^{5}$ Olivia Chirobocea. "Perspectives on Postmodernism and Historical Fiction", Journal of Romanian Literary

Studies,(2017). 233-242.
} 
Poppies (2008), which are all primarily based in India. Gosh highlights the national issues which, actually, require urgent focus and treatment. His work displays not only his creative aspect but, also, his profound commitment to humanity, justice, tolerance, pluralism, truth, democracy and history of his nation. Moreover, his significant thematic concern to use the journey as a space, where boundaries or barriers are dissolved, makes him contemporary Indian novelist who stands at par with global English fiction writers.

Kamila Naheed Shamsie, a well-known and contemporary English novelist, was born in Karachi. She studied MFA from the University of Massachusetts, at Amherst. She has written seven novels to date. In 1999, she was honored with the Prime Minister's Award for Literature, awarded by Pakistan Academy of Letters. At present, being a dual citizen; Shamsie divides her time in Pakistan and London. She is a human right activist, team member of English PEN, a trustee of FWC (Free Word Centre) and a contributor to the famous newspaper The Guardian. Her fifth novel Burnt Shadows (2009) was nominated for the Orange Prize for Fiction and it also won the Danish Literature Prize ALOA-2010. This novel, so far, has been translated into twenty-one languages. Shamsie weaves political, historical and social in Burnt Shadows. The novel begins on August 9, 1945, in Nagasaki, and it ends in a prison cell in the US in 2002, as a man (named Raza) is waiting to be sent to Guantanamo Bay. In fact the novel is an epic narrative of love, friendship and betrayal. Hiroko Tanaka is a twenty-one year old woman who is in love with the man she is to wed, Konrad Weiss. As she steps onto her veranda, being very happy at the thought of her marriage, wrapped in a kimono with three black cranes swooping across the back, her world suddenly comes to an end. The horrible memory of the atomic bomb retains with her in the form of three bird-shaped burns on her back. Hiroko afterwards leave Japan and travels to Delhi to stay with Konrad's half-sister, Elizabeth. Here she meets Burton's employee Sajjad Ashraf, from whom she starts taking language classes to learn Urdu. After the partition of India, and the division of the subcontinent in India and Pakistan, Hiroko finds herself displaced once again, in a city where old conflicts are replaced by the new ones. The novel reflects on the shadows of personal as well as political history where the interrelated worlds of the Burtons, the Ashrafs, and the Tanakas as connected through the symbolic presence of a spider. It constructs and transforms the facts of the past in such a way that reality, history, and fantasy become one and it relates national events with that of personal ones. The rebellious characters challenge the government and military such as Hiroko's Father who does not believe in state's policies. Shamsie connects past with present and future as the novel is based on historical events as well as whatever is happening in the current decade as well as she warns about the possible impact on future. Duce in a research study states (quoted):

Spanning five centuries, Shamsie's Burnt Shadows, shortlisted for the 2009 Orange Prize, rests on violent clashes of global significance: the atomic bombing of Nagasaki in 1945, the partition of India and the formation of Pakistan in 1947, and the consequences of 9/11 in Afghanistan and America in 2001-2002. ${ }^{6}$

\footnotetext{
${ }^{6}$ Olivia Chirobocea. "Perspectives on Postmodernism and Historical Fiction.", Journal of Romanian Literary Studies,(2017). 233-242.
} 
The Glass Palace, as a postmodern historiographic metafiction, challenges the legitimacy of the master narrative of conventional history that perpetuates a specific version of history. It problematizes narrativization of the past as the story links history with myth, imagination, and constructed-ness. It is because of these very features, that this novel can be placed in the genre of historiographic metafiction. The text, instead of the modernist approach of tracing cause and effect, focuses on human relationship, communication, the status of knowledge, and indeterminacy.

\section{Literature Review}

The term 'postmodernism' is defined by a variety of interpretations and, due to this reason; it has created confusion and controversies among different theorists. At present, either it is celebrated or condemned but, it, significantly, represents the contemporary world, and it's influence on an individual's life. The theorists namely Linda Hutcheon, Jurgen Habermas, Ihab Hassan, Jean-Francois Lyotard, Fredric Jameson, and Jean Baudrillard have proposed their understanding of postmodernism. Though, their attempts could not define the movement in an absolute way, as this trend is currently in practice and ongoing, hence it is always vulnerable to change. A research study entitled "Perspectives on Postmodernism and Historical Fiction" states that "Ihab Hassan browses history looking for mentions of this term and finds it used for the first time in 1934 by Federico de Onís in his Antología de la poesía española e hispanoamericana".,

Historiographic metafiction is a term that was coined in the 1980's by a well-known Canadian theorist Linda Hutcheon. She, in her renowned book titled A Poetics of Postmodernism (2005) states that these (historiographic metafiction novels) are "wellknown and popular novels which are both intensely self-reflexive and yet paradoxically also lay claim to historical events and personages". ${ }^{7}$ According to Hutcheon, such novels deconstruct every element of traditional historical narrative fiction as they blur the boundary between fact and fiction and in this way problematize the modern construction of past events. They employ unstable protagonists who do not have any fixed ideas about themselves and their past in contrast to the traditional subject who is the reliable authority in actualizing her/himself and narrating the past events. Instead of a monolithic voice, such novels weave multiple narrators/perspectives and in this way prompt the reader to work hard to attain any understanding. In contrast to traditional linear record of conventional historical representation, the novel employs an anti-linear time sequence and different locations. Rational exposition of the novels with a proper beginning, middle, or end where traditional closure is replaced by an arbitrary end. The incorporation of these postmodern features make such fiction unique, from the traditional fiction, as these texts also incorporate problematization of national identities, race, class, gender, culture as well as the matters of religious understanding.

Historiographic metafiction is self-consciously subjected to the narration of the past as it combines metafictional elements with three genres mainly i.e. literature, theory, and history. In fact, "the crossing of boundaries between fact and fiction, history and myth,

\footnotetext{
${ }^{7}$ Linda Hutcheon. A Poetics of Postmodernism: History, Theory, Fiction. (London: Routledge, 2003), 5.
}

${ }^{8}$ Ibid. 
historiography and historical fiction, individual stories and collective history have become one of the hallmarks of postmodernist historical novels". ${ }^{9}$ It blurs the conventional separation of literature and history as both are intertextual as well as linguistic constructs. It probes the literary aspect of history by asking questions about it's traditional interpretations as according to Hutcheon, historiographic metafiction subverts its own conventions as it plays and casts doubts on historical facts. It implies its fictionality and materialization of the real historical events. Such novels play upon both; truth and falseness of the past and due to the presence of multiple meanings and reality(s), historiographic metafiction reflects that truth is not a graspable entity rather it is multiple in nature. These novels reflect upon this potential to approach conventional truth as their fictional characters possess a certain degree of historical consciousness, and they question and expose that whose truth has been told. Hutcheon states:

They have both been seen to derive their force more from verisimilitude than from any objective truth; they are both identified as linguistic constructs, highly conventionalized in their narrative forms, and not at all transparent either in terms of language or structure; and they appear to be equally intertextual, deploying the texts of the past within their own complex textuality. ${ }^{10}$

In the Indian literary scene, postmodern historiographic metafiction emerged with the publication of Salman Rushdie's Midnight's Children in 1981. Many other contemporary English novels are also writing about many past events including Partition of the subcontinent, September 9/11 and others. Similarly, Burnt Shadows as a historiographic metafiction writes over the debate of the atomic bombings of Hiroshima and Nagasaki for ethical and legal concerns. Many researchers and scholars have written about the event as Noam Chomsky states, "Even the little bit of information that came across was that one plane had flown across to an undefended city and dropped one bomb, which they then described and the number of people they had killed. But it was obviously monstrous. That does open a new era, no question" ". Similarly, The Glass Palace traces the personal and political history through the depiction of different characters and events. As Chitra states:

The Glass Palace is a saga about three generations of two closely linked families in Burma, India and Malaya from 1885 to 1956. It is also a historical novel about the British colonization of Burma. When imperialism divides and partitions set limits to freedom, the characters in the novel spil so easily over national and family boundaries through friendship and marriage that it becomes difficult to pinpoint a character's affliation an exclusively Indian or Burmese or Chinese or Malay. This novel is more than merely a revisionary rewriting of a portion of the history of the British Empire from the perspective of the colonized subaltern. ${ }^{12}$

\footnotetext{
${ }^{9} \mathrm{Ibid}$.

${ }^{10}$ Ibid., 105.

${ }^{11}$ Ansgar Nünning, Crossing Borders and Blurring Genres: Towards A Typology and Poetics of Postmodernist

Historical Fiction in England since the 1960s" European Journal of English Studies, (1997)

${ }^{12}$ Ibid.
} 


\section{Research Methodology}

The present study is descriptive and qualitative. The data comprises of two novels The Glass Palace and Burnt Shadows, and textual analysis is used as a research method that focuses on the setting, characters, and events, from the texts. The research explores the impact of various historical events on the lives of characters as how they feel or react in a particular situation. The selected texts are studied in different components like words, sentences, phrases, and idioms.

\section{Significance of the Study}

This research is significant as it deconstructs the conventional divisions between history and fiction. It explores that how the selected texts generates mini or micro-narratives through the subaltern or marginalized characters and hence it provides multiple historical reality (s). In this way, the current study replaces the historical absolute "truth" with multiple truths through imaginative constructed-ness of the literature.

\section{Research Objectives}

This study is based on the following objectives:

1. To explore the extent to which the novels Burnt Shadows and The Glass Palace exhibit significant features of historiographic metafiction.

2. To investigate the detailed aspects in which the novels Burnt Shadows and The Glass Palace contest absolute and objective history.

\section{Research Questions}

On the basis of research objectives, this study investigates the following questions:

1. How do the novels Burnt Shadows and The Glass Palace exhibit certain significant features of historiographic metafiction?

2. At what extent the novels Burnt Shadows and The Glass Palace contest absolute and objective history?

\section{Textual Analysis}

Burnt Shadows is divided into four parts, which are titled separately and each part is based on a specific period of time. Part one is based on Nagasaki atomic bombings of 1942 but Shamsie; as a fiction writer, takes the liberty to replace the exact date with 1945. Part two revolves around 1947 partition of the sub-continent, while the third part debates on the present-day political situation such as the 1982 nuclear's explosions by India and Pakistan. The fourth and last part is on post 9/11 period and the War on Terror and it covers the time span ranging from 2001 till present. Burnt Shadows, as historiographic metafiction, tells that what happens to human beings in the face of fatal tragedies. It is one of the longest novels of Shamsie, which depicts the lives of characters 
such as Konrad; who dies as a result of American bombing, Hiroko; who has to migrate to India to start a new life and Sajjad; a Muslim, who has to move to Pakistan as a result of partition 1947. The novel reflects that as a result of certain tragic events, these characters lose their identities, places and land properties.

Shamsie combines together multiple perspectives on certain historical events, and different characters re-tell and perform a parody of these events. Burnt Shadows, being based on a globalized context, highlights how different characters from East and West, formulate their relationship not on the basis of their bloodline but on the basis of humanity. Konrad, the German character, reflects this very spirit when he tells Hiroko that ".......barriers are made of metal that could turn fluid when touched simultaneously by people on either side.....". ${ }^{13}$ The character of Hiroko is also problematic as she also carries a changing spirit of the time and, her, this, very characteristic, shows that one needs to stay true to one's own self irrespective of the chaos of the outside reality. Her personal experiences are juxtaposed with that of national and global events and, in this way, they subvert the objectivity of traditional historical discourse. Nishat Haider states that "History is always a matter of telling a story about the past, using other texts as intertexts. History is not a matter of dates and great events but of politics, ideology, power, authority, and subversion". ${ }^{14}$ The novel as historiographic metafiction also contests the notion of a single and fixed narrative voice by giving the proponents of every group a distinct space to express their anguish against literary historical seclusion in order to challenge absolute history. The fictional description of Nagasaki and Hiroshima atomic bombings in form of Hiroko's and Konrad's love affair, and Konrad's death and two blank pages after the narration of his death, speaks of the creative presence of Shamsie, as an artist, who draws attention towards novel as a work of art.

Intertextuality, a significant feature of historiographic metafiction, is evident in Burnt Shadows in the form of allusions, parody, idioms, words, and phrases taken from different texts such as E.M Forster's A Passage to India etc. Moreover, the novel also incorporates the historical figure of Razia Sulatna; a Muslim woman ruler, when Sajjad appreciates her bravery. At other point, Raza( Hiroko's son) sees the history book and he notices the horrors of atomic bombing of Heroshima and Nagasaki and is horrified as Linda Hutcheon in her book A Poetics of Postmodernism states, "The intertextual parody of historiographic metafiction enacts, in a way, the views of certain contemporary historiographers: it offers a sense of the presence of the past, but a past that can be known only from its texts, its traces-be they literary or historical". ${ }^{15}$ In the line of Hutcheon's rgumentation, Burnt Shadows incorporate other texts in order to re-tell and comment on the past.

Shamsie, through the character of Hiroko, incorporates themes such as identity crisis that makes the character as alienated and she experiences a kind of self destruction also known as paranoia i.e. a state of schizophrenia. Hiroko, by contrast, and in the sense of

\footnotetext{
${ }^{13}$ Kamila Shamsie, Burnt Shadows (London: Bloomsbury, 2009), 82

${ }^{14}$ Nishat Haider. "Shashi Tharoor's Riot: A Novel about the Construction of Identity, the Nature of Truth, Representing and the Ownership of History." South Asian Review, (2006)

${ }^{15}$ Kamila Shamsie, Burnt Shadows, Op.Cit., 82
} 
historiographic metafiction problematizes her own identity as she lacks a stable vision and unity about herself. Her religious and national identities are complicated, and this functions as a means of preventing her from formulating a coherent identity. On the other hand, in a traditional historical narrative, the identity of the subject is never problematized. Her psychological trauma that leads her to paranoia is reflected through the use of techniques like memory, intertextuality, multiculturalism and nonlinear, in addition to the postmodern multiplicity of plot in the novel. Shamsie highlights the imperialism of the west through the brutal holocaust of Hiroshima and Nagasaki in 1942, and she also exposes the opposition that is present between orient/occident, margin/center and colonizer / colonized. The novel also deals with the trauma of dislocation as Hiroko migrates to various geographical settings where she forms a new identity in order to escape from her bitter and violent past. Similarly, there are many other characters who share and represent their history as:

Sajjad narrates the history of Qutb Minar to the Anglo-Indian representative Elizabeth. He tells about his family history that his ancestors were soldiers in the armies of Mamluks. They are the first dynasty of the Delhi Sultanate, Qutb-ukdin Aibak after whom the minaret has been named. While doing this, he thinks that, "... this is how things should be - he an Indian, introducing the English to the history of India, which was his history and not theirs". ${ }^{15}$

The novel creates a strong link between the past and the present through an experimental blend of flashbacks and memory. It re-writes and constructs the history of the colonized, the immigrants, and the minority, and it transforms them in order to bring the oppressed at the center of the global world. Patricia Waugh, another leading postmodern theorist, comments on the use of language as a tool as she states, “"Language constructs rather than merely reflects everyday life". ${ }^{16}$ Sajjad gets upset at the colonization of his land and he compares the conquerors of different time stands when he says that "throughout India's history conquerors have come from elsewhere, and all of them Turk, Arab, Hun, Mongol, Persian- have become Indians. If- when- this Pakistan happens, those Muslims who leave Delhi and Lucknow and Hyderabad to go there, they will be leaving their home. But when the English leave, they'll be going home." 16

The novel explores past with a critical eye as it presents new approaches to history, it does not assign any positive meaning to history as a progress rather it offers an alternative and non-progressive perspectives. Hiroko describes her experience of the tragic happening of the 1942 bombing in these words:

It throws Hiroko forward, sprawling. Dust enters her mouth, her nose, as she hits the ground, and it burns. Her first response is a fear that the fall has torn her mother's silk Kimono. She raises herself off the ground, looks down. There is dirt on the Kimono, but no tear. She glides her hand over her shoulder, touches flesh where there should be silk. Moves her hand further down her back, touches what is neither flesh nor silk but both. She wonders if this has something to do

\footnotetext{
${ }^{16}$ Patricia Waugh. Metafiction: The Theory and Practice of Self-conscious Fiction. (London: Methuen, 1984),
} 
with the burning she felt as she fell. Now there is no feeling. She taps the place that is neither flesh nor silk. There is no feeling at all. ${ }^{17}$

Burnt Shadows rewrites the history of different countries, including Japan, India, Pakistan, Afghanistan, and America. Mark Stein appreciates this very characteristic of Shamsie's fiction that undermines the " habitual classification of literary texts in terms of national or regional literature" (qtd in A Critical Analysis of Kamila Shamsie's Burnt Shadows) ${ }^{18}$ In fact, this multiplicity of literary styles is another important characteristic of the novel that makes it a historiographic metafiction. Shamsie constructs each chapter while using forms such as poem, epistolary narrative, prose, case history, traditional realism, documentary, and the reader has to work hard in order to make sense of the events narrated. Moreover different settings, geographies and time strands also confuse the reader's understanding and "The Prologue" starts the novel from the end as it "call attention to the impossibility of a totalizing narrative structure". ${ }^{19}$ The novel's concern is global, and Shamsie relates the fiction with history of different continents as she, in her one interview, states that:

Fiction writers go where news reporters and historians dare not tread: into characters' heads, into the dreams they lose at the moment of waking, into the memories forgotten, the fears never articulated even to themselves. We do all this, even while making stuff up or distorting and embellishing "what really happened" for the sake of a dramatic arc; and, in so doing, we claim our ability to convey emotional truths, more revelatory about a time and place than any series of facts (The Guardian). ${ }^{20}$

The novel represents the disasters that the world has experienced, as a consequence of wars or conflicts, that has not only destroyed human being but also non-human creature such as animal, plant and sea etc. The novel presents historical events on the basis of personal and subjective experiences of the characters along with national impact. Hiroko Tanaka and Konrad fall in love and they are about to get marry when Nagasaki atomic bombings occur and it brings huge human destruction. There was no dead body left as everything including the human being, animal, forest, and building melt down, and Hiroko was able to discover only signs of Konrad's (possible) dead body when she says that:
"There, see? There."
"How can you be so sure it's him?"
"No one else in Nagasaki could draw such a long shadow". ${ }^{21}$

It is due to the after-effects of atomic bombings that Hiroko delivers only one son, who is born after several miscarriages and after him, she could not get pregnant as a result of

\footnotetext{
${ }^{17}$ Kamila Shamsie, Burnt Shadows, 75.

${ }^{18}$ Iman. M. Omaishat. A Critical Analysis of Kamila Shamsie's Burnt Shadows. M.A theses. (Middle East University, 2015).

${ }^{19}$ Linda Hutcheon. "Subject in/of/to History and His Story." Diacritics 16.1 (1986): 78-91.

${ }^{20}$ Shamsie (interview), More Honest than the Facts, (UK: Guardian, 2007)

https://www.theguardian.com/commentisfree/2007/jul/03/comment.pakistan. (Assessed 22 ${ }^{\text {nd }}$ Dec 2018).

${ }^{21}$ Kamila Shamsie, Burnt Shadows, (London: Bloomsbury Publishing, 2009), 29.
} 
some permanent harm that happened to her body as well as mind. Hiroko highlights the devastating post-war condition of Afghanistan when she says that, "After two decades of war, barely anything lived here other than juniper bushes and small groups of villagers". ${ }^{22}$ The Prologue of Burnt Shadows presents a very terrifying image of a person, who is detained and his unclothed physical appearance shows the level at which humanity has reached, in dehumanizing a human being. The text describes the negative impact of the atomic bombing on non-human elements like earth, plants, and mountains as it writes:

Hiroko asks if there were an adjective to best describe how changed Nagasaki has, she decides, that would be it. Everything distilled or distorted into its most functional form. She walked past the vegetable patches on the slopes a few days ago and saw the earth itself furrowing in mystification: why potatoes where once there were azaleas? What prompted this falling-off of love? How to explain to the earth that it was 62 more functional as a vegetable patch than a flower garden, just as factories were more functional than schools and boy. ${ }^{23}$

Partition of the subcontinent in 1947 is another historical event that the novel highlights in terms of it's after-effects that caused lives of innocent men, women and children, their homes and properties. The characters, in the novel, reflect their perspective as Pervz states that"Sajjad never ever wanted to leave Dilli. To Dilli he always said his Dill (heart). Hindus and Muslims have lived together form thousands years, and in this duration India had been attacked by different conquerors, but the concept of separation never occurred". ${ }^{22}$ Similarly, Hiroko and Sajjad; face the consequences of partition riots during and after the event, and they are compelled to move to Pakistan. Their lives are shattered due to unpredictable present, and, future that they might encounter. The text writes about their confusion as:

Exiled from Dilli, they settle in Karachi and raised, Raza, their son, their lives are overtaken by cold war perils: the threat of nuclear war between India and Pakistan; the growing repression under the US-backed Pakistani military dictatorships; and the shadowy and ubiquitous presence of the CIA and its alliance with Pakistan's ISI (Inter-Services Intelligence). As the agencies police the Pakistan / Afghanistan border, reaching into the border camps and far beyond, Raza is drawn into the intrigue, deceit, and divided loyalties of private military corporations. ${ }^{24}$

The above-mentioned extract, shows that even in their own independent country they don't feel safe rather they live in a constant shadow of a possible much rumored, nuclear explosion. At the end of the novel, their fear proves true, as Hiroko losses her son who is, mistakenly, captured by CIA and is, now, placed in detention. She, though a survivor of atomic bombings, never attains inner strength to bear any loss and, hence remains, permanently, upset physically as well as mentally. Hiroko's tragic past accompanies her in her present and future too, as she is known as 'atomic bomb survivor'. The text reveals that she wants to run away from horrible memories of her past when she says to

${ }^{22}$ Ibid., 7

${ }^{23}$ Ibid., 256

${ }^{24}$ Ibid., 279 
Elizabeth, 'I don't want to hide these burns on my back, but I don't want people to judge me by them either. Hibakusha. I hate that word. It reduces you to the bomb. Every atom of you". ${ }^{25}$ Such representation questions the modern narratives of science, advancement, power, government, justice and enlightenment as Horkheimer claims, "Enlightenment is totalitarian". ${ }^{26}$ These grand narratives preach utopian impulse while in fact there is no connection between the so-called modern claims to uplift the standards of society with that of horrific Hiroshima atomic bombing attack in 1945.

The formal structural pattern of The Glass Palace is divided into seven sections, of varying space and length, while the main characters, of the novel, remain constant. It is a mixture of tragedy, romance, seriousness, comedy, fantasy, gross reality, mystery, prose, verse, history, and politics. Moreover, it is an experimental fusion of English, informal slangs, and words from various local languages. There is no division of disciplines followed, especially, between history and politics as "Rethinking History: A study of Shashi Tharoor's Riot as a Postmodern Historiographic Metafiction" states that, "According to the postmodern theoreticians, the boundaries of history and fiction are porous". ${ }^{27}$ Historiographic Metafiction as a postmodern genre is distinguished from the historical novel in its perception of the truth that is, particularly, related to the past as it engages itself in "the process of critically examining and analyzing the records and survival of the past". ${ }^{28}$ Such novels explore the plurality of truth as The Glass Palace exemplifies this postmodern view in its narrative, and the characters subvert the conventional historical narratives. Moreover the protagonist, Rajkumar is himself unreliable narrator due to his very young age i.e. eleven years old. The novel first endorses the truthfulness of the narrator Rajkumar when it writes as "There was only one person in the food-stall who knew exactly what that sound was that was rolling across the plain". ${ }^{29}$ After launching the reliability of the protagonist, The Glass Palace raises a doubt about his authenticity when it states that, "his name was Rajkumar and he was an Indian, a boy of eleven - not an authority to be relied upon". ${ }^{30}$ The novel problematizes the traditional understanding of the subject, which is another characteristic of historiographic metafiction. In traditional historical discourse, the historian is a unified subject with a consistent vision who presents past accounts objectively by rationally narrating them. On the contrary, Rajkumar as the eleven years old subject cannot be relied in his analysis and interpretation, therefore creates a doubt about the historical events. The Glass Palace depicts various perspectives on different historical figures as Dinu; a character condemns Mussolini and Hitler for their violent interference in Europe. He says that, "Hitler and Mussolini are among the most tyrannical and destructive leaders in all of human history. They're grotesque they're monsters". ${ }^{31}$

${ }^{25}$ Kamila Shamsie, Burnt Shadows. (London: Bloomsbury Publishing, 2009), 230.

${ }^{26}$ Max Horkheimer \& Theodor W. Adorno. Dialectics of Enlightenment. Ed. Gunzelin Schmid Noerr. Trans. Edmund Jephcott. (California: Stanford UP. 2002), 4.

${ }^{27}$ Parween, Shagufta. "Rethinking History: A Study of Shashi Tharoor's Riot As a Postmodern Historiographic Metafiction", International Journal of Innovative Research and Development (2014).

${ }^{28}$ Linda Hutcheon. A Poetics of Postmodernism: History, Theory, Fiction. (London: Routledge, 2003),92

${ }^{29}$ Amitav Gosh, The Glass Palace: (India: Ravi Dayal, 2000 ), 3.

${ }^{30}$ Ibid.

${ }^{31}$ Ibid., 293 
Amitav Gosh presents diverse views of the characters as there is no uniformity in the opinion(s) to be found in the novel such as Arjun; as an Army officer believes on the policies of British rule while Uma, a lady activist, disagrees on this idea of having blind faith on English rulers. Arjun justifies his stance by saying that if Japan occupies their country (India) then it will prove itself a bad master while English people are a good ruler. He gets surprised when once he encounters a group of Indian students who blame him for his blind faith in English masters. Arjun tries to convince them by saying that, "We aren't occupying the country. We are here to defend you". ${ }^{32}$ The activists reply in an anger that; "From whom are you defending us? From ourselves? From other Indians? It's your masters from whom the country needs to be defended". ${ }^{33}$ On the contrary, Hardayal, also known as Hardy, is a soldier and a friend of Arjun, who feels a disintegration in his personality due to confusion between his loyalties. He challenges the British force's claim that promises to safeguard the colonized nations when he asks Arjun:

Well, didn't you ever think: this country whose safety, honor and welfare are to come first, always and every time what is it? Where this country? The fact is that you and I don't have a country - so where are this place whose safety, honor and welfare are to come first, always and every time? And why was it that when we took our oath it wasn't to a country but to the King-Emperor - to defend the Empire? ${ }^{34}$

The Glass Palace consists of seven sections, and each part highlights the various perspectives on history while the setting of the novel is the year of 1885; during AngloBurmese war. The second part of the novel is named as 'Ratnagiri', and it is again based on imperialistic occupation of Burma by British. The text and the characters show that people feel divided in the clash of the governments while in traditional history some ethnic, gender, or ideological groups are almost always excluded from the main narrative. However, in postmodern historical fiction such excluded groups find a place in the representation. Hutcheon places these groups as they are not in the center and are treated as "ex-centric". ${ }^{35}$ The Glass Palace narrates the little stories of historical changes from the common man's point of view. The third part is titled as 'The Money Tree' that is based on the character of Rajkumar who, despite being alone and an orphan, progresses in the timber business. The fourth part of the novel is 'The Wedding' that revolves around the second generation characters such as Neel; Rajkumar's son, who marries Manju. The fifth part is named as 'Morning Side' that reflects the bitter consequences of World War Two with reference to its effect in Malaya. Next section 'The Front' reveals how various characters suffer as a result of the War. The title of last part, of the novel, is the same as the title as it is named 'The Glass Palace', and this chapter narrates that how Indian National Movement starts and attains a peak and helps India, finally, achieves independence.

The text records personal and national narratives of the characters, that expose the happenings in Anglo-Burmese war and the King's exile as narrative situation

\footnotetext{
${ }^{32}$ Ibid., 287.

${ }^{33}$ Amitav Gosh, The Glass Palace: (India: Ravi Dayal, 2000 ), 3.

${ }^{34}$ Ibid.

${ }^{35}$ Linda Hutcheon. A Poetics of Postmodernism: History, Theory, Fiction. (London: Routledge, 2003),68.
} 
"particularly in modernist and postmodernist fiction hardly ever occur in their pure form; individual literary works are often hybrids combining elements of various types of narrative situations". ${ }^{36}$ During the exile of Burmese King and Queen, two security ministers, namely Taingda and Kinwun Mingyi guard the Royal family, and they seem happy as they know that they will be getting better rewards from the English rulers. They also hand over King Thebaw, Queen Supayalat, and their daughters, and this section of the novel is named Mandalay. This part reflects that how English rulers forced exile on the Burmese royal family and it, ironically, expose the attitude of a public that, initially, stays loyal to their master but, with the end of their rule, they started looting the palace. British guards and soldiers who are responsible to shift the queen's precious ornaments from the royal palace to the ship, also, take advantage and steal the precious jewels as it is never represented in the traditional history and may be "an indication of "possible mnemonic failures of recorded history". ${ }^{37}$ Through the depiction of such characters, Ghosh exposes the lust, that exists in human nature and it compels the man to even get brutal towards his own fellows in the time of crises. This lust equally compels the ordinary Burmese public and British soldiers, to loot the palace, and their this act shows the sameness in human beings irrespective of differences of caste, race, nations and religion. Multiple narrators are other aspects of the novel that separates it from a traditional historical fiction where usually an omniscient third-person narrator exposes the reality. There are narrative perspectives of Dolly, Saya, Rajkumar, Neel, Umma and many others and in this way "the narrative unity within each section of the novel is disrupted by the start of another section with a different point of view". 38 The novel does not give a proper closure as in the words of Hutcheon it is called "the perfect anticlosure" ${ }^{39}$ Moreover, the novel reflects the combination of two different discourses i.e. fantastic and historical. It is fantastical because it portrays the illusions, dreams and visions of characters such as Dolly, Dinu and Rajkumar while it is historical because it narrates the story of the Burmese King's exile. This simultaneous presence of two different discourses makes the novel different from a traditional historical fiction. There is notable conversation between Dolly and her friend Uma who raise question on established beliefs and historical facts. On one occasion Uma, the wife of the Indian Collector asks Dolly about the cruelty of Queen Supalayat and in reply Dolly makes Uma look at the situation from her point of view:

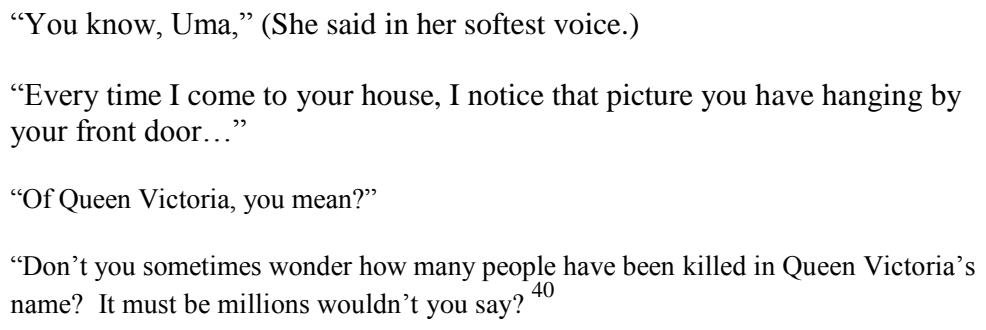


These lines show that the characters in The Glass Palace are no passive rather they resist retaliate and generate their discourse to reflect their opinion. There are other characters like Arjun, Dolly, Saya and Neel who challenge the master narratives of history by telling their own version of different historical events.

\section{Conclusion}

The study has evaluated The Glass Palace and Burnt Shadows as historiographic metafiction, and it has found that these novels do blend historical record with the personal narratives. The selected novels decentralize and rewrite the great historical tales through the mouthpiece of various peripheral characters such as minority, women, and children. The novels problematize the difference between fact and fiction by incorporating certain postmodern strategies that are quite different from what is expected of traditional fiction. The selected novels emphasize intertextuality, unstable protagonists, multiple literary genres, nonlinear plot, multiple narrators and arbitrary closure The research concludes with the findings that the selected novels can be labeled as historiographic metafiction due to the presence of these features. Moreover, these texts question conventional history as a metanarrative that claims to be universal, absolute and progressive. The presence of various characters and their multiple stories challenge historical objectivity, authenticity, and authority over truth. The novels also use various historical figures and events such as Nagasaki and Hiroshema atomic bomb attacks and King Thebaw of Burma and in this way these texts create confusion as to the boundary between fact and fiction and finally undermine the historical representation in fictional as well as nonfictional historical writings. This study finds that historiographic metafiction calls into question the conventional beliefs about the fixed subject and rationalism and it deconstructs the major standpoints of modernity.

\section{Bibliography}

Chirobocea, Olivia. "Perspectives on Postmodernism and the Historical Fiction". Journal of Romanian Literary Studies, 10 (10), 233-242. (2017).

Duce, Cristy Lee. "In Love and War: The Politics of Romance in Four 21st-century Pakistani Novels." (Diss. University of Lethbridge, Canada, 2011).

Ghosh, Amitav. The Glass Palace: A Novel. (India: Ravi Dayal, 2000).

Haider, Nishat. "Shashi Tharoor's Riot: A Novel about the Construction of Identity, the Nature of Truth, Re-presenting and the Ownership of History". South Asian Review, 2 (27), 235-260. (2006).

Horkheimer, Max \& Theodor W. Adorno. Dialectics of Enlightenment. Ed. Gunzelin Schmid Noerr. Trans. Edmund Jephcott. (California: Stanford UP. 2002).

Hutcheon, Linda. "A Poetics of Postmodernism?." (1983): 33-42. 
Hutcheon, Linda. "Subject in/of/to History and His Story.” Diacritics 16.1 (1986): 78-91.

Jaggi, Maya. "When World Collides." The Guardian. (2009).

Klarer, Mario. An Introduction to Literary Studies. (New York: Routledge, 2013).

King, Bruce. "Kamila Shamsie's novels of history, exile and desire." Journal of Postcolonial Writing. 2 (47), 147-158. (2011).

Jenkins, Keith. Re-thinking History. (London: Routledge, 1991).

Lyotard, Jean-François. The Postmodern Condition: A Report on Knowledge. Vol. 10. U of Minnesota Press. (1984).

Marshall, Brenda. Teaching the postmodern. (New York: Routledge, 2013)

Nicol, Bran. The Cambridge Introduction to Postmodern Fiction. (Cambridge: Cambridge UP, 2009).

Nünning, Ansgar. "Crossing borders and blurring genres: Towards a typology and poetics of postmodernist historical fiction in England since the 1960s." European Journal of English Studies 1(2), 217-238. (1997)

Omaishat, Iman M. A Critical Analysis of Kamila Shamsie's Burnt Shadows. (Diss. Middle East University, 2015).

Parween, Shagufta. "Rethinking History: A Study of Shashi Tharoor's Riot As a Postmodern Historiographic Metafiction." International Journal of Innovative Research and Development 3(2), 56-60. (2014).

Pervez, Waheed. "Critical Study of Shamsie's Novel Burnt Shadows in the Light of Postcolonial Theory" International Researchers, 7(2),38-43. (2018).

Shafique, S., \& Yaqoob, M. (2012). "Kamila Shamsie's Burnt Shadows as an Intertextual re-writing of Forster's A Passage to India". Academic Research International. 2(1), 477486. (2012).

Shamsie, Kamila. Burnt shadows. (London: Bloomsbury Publishing, 2009).

Shamsie, Kamila. "More honest than the facts." Guardian. co. UK, (2007)

Swift, Graham. Waterland. Picador. (2010).

Waugh, Patricia. Metafiction: The Theory and Practice of Self-conscious Fiction.

(London: Methuen, 1984). 